К. В. Лифбанов (Москва, Россия)

\title{
Дивергенция словацкого и чешского литературных языков в XX в. на грамматическом уровне (на примере числительных)
}

Классическая контактная лингвистика вслед за У. Вайнрайхом (Вайнрайх 1979) исходит из того, что в результате языкового контакта возникают разного рода интерференции языковых элементов, которые либо реализуются в речи индивидов, либо вследствие их повтора становятся явлениями языка. Считается, что последствием языкового контакта является конвергенция языков. В связи с этим именно конвергентные процессы находятся в центре внимания лингвистов, изучающих контактные явления в чешском и словацком языках.

Соотношение конвергенции и дивергенции, однако, является более сложным. Как отмечал Е. Д. Поливанов, «чрезвычайно частым (и, так сказать, типичным для историй всех языков) явлением оказывается одновременность и взаимная обусловленность конвергенции и дивергенции, причем дивергенция может рассматриваться как обратная сторона (изнанка) конвергенционного процесса, и обратно» (Поливанов 1968: 111). Изучение взаимодействия словацкого и чешского литературных языков в XX в. наглядно демонстрирует, что в условиях интенсивного языкового контакта при доминирующем воздействии чешского языка на словацкий в последнем происходят очевидные дивергентные процессы. При этом они реализуются на разных языковых уровнях. В данной статье рассмотрим изменения дивергентного характера в словацком литературном языке, затронувшие грамматические свойства числительных.

В качестве исходной точки в развитии грамматических свойств числительных в XX в. нами принимается состояние, 
зафиксированное главным образом в газете «Католицке Новины» за 1889-1890 гг. (Katolické Noviny 1889-1890).

Одним из наиболее существенных процессов модификации грамматических свойств числительных в XX в. стало изменение соотношения словообразовательных моделей сложных/ составных числительных, которые могут образовываться двумя способами, когда единицы предшествуют десяткам или следуют за ними. Первая модель (типа јеdenadvacet) является основной в чешском литературном языке, тогда как вторая (dvacet jeden) употребляется в нем «при диктовке цифр, в арифметике и вообще в специальном языке» (Šmilauer 1972: 197). В словацком литературном языке первоначально обе модели (jedenadvadsat' и dvadsatjeden) употреблялись в равной степени, однако с течением времени происходит изменение их статуса, и уже в «Кратком словаре словацкого языка» 1987 г. отмечается, что первая модель стала разговорной и устаревает ${ }^{1}$ (Krátky 1987: 283).

В первой половине XX в. происходит сращение составных числительных, состоявших из десятков и единиц, которые стали восприниматься как одно слово. Последствием этого стало изменение синтаксической связи составных числительных с компонентами $d v a$, tri, štyri. Еще в конце XIX в. и в первые десятилетия XX в. указанные числительные, как и в чешском литературном языке, соединялись с формами существительных в именительном падеже множественного числа. Ср. примеры:

(a) Dl’a najnovšieho sčítania obýva Europu viac než 100 millionov Slavianov, asíce: 53 milliony Rusov; 15 millionov Rusínov; 13 1/2 milliona Poliakov... Spolu blízko 102 milliony (Katolické Noviny 1890: 54);

(b) Martin Bartoš dostal 64 palice, Juro Junáček 50 palíc, Pavel Rus 40 a Štefan Vrabec, ktorý pre svoj vysoký vek nebol by viacej vydržal, 24 palice (Škultéty 1920: 20).

1 См. пометы у числительного pätadvadsat. 
Позже выделенные курсивом формы им. и вин. падежей мн. числа были вытеснены соответствующими формами родительного падежа множественного числа: 53 miliónov, 102 miliónov, 64 palíc, 24 palíc.

Этот процесс сопровождался утратой категории рода компонентов jeden и dva составных числительных. Так, в «Правилах словацкого правописания» 1931 г. допускаются дублетные образования с различением рода и без него: dvacat'jeden človek, dvacat' jedna žena, dvacat'jedno diet'a; dvaciati dvaja l'udia, dvacat'dve ženy, dvacat'dve mestá - dvacat' jeden l'udi, žien, detí; dvacat'dva l'udí, stromov, žien, detí (Pravidlá 1931: 64). В правилах же правописания 1940 г. кодифицируются уже только числительные, управляющие формами род. падежа мн. числа существительных, однако родовые характеристики при этом сохраняются: dvadsatjeden vojakov, dvadsatjedna žien, dvadsatjedno deti, dvadsat'dva vojakov, dvadsat'dve žien, dvadsat'dve miest (Pravidlá 1940: 100). И только в кодификации 1954 г. составные числительные приобретают современные фрормы: dvadsatjeden vojakov, žien, detí, dvadsat’dva vojakov, žien, miest (Pravidlá 1954: 88).

Также в XX в. произошла дифрференциация форм собирательных и видовых числительных. В конце XIX — начале $\mathrm{XX}$ в. с фрормальной точки зрения числительные dvoje, troje, oboje, как и в чешском литературном языке, могли выступать в фоункции как собирательных, так и видовых числительных. Кроме того, названные числительные еще со времен кодификации Л.Штура склонялись (Štúr 1957: 221-222), хотя и несколько иначе, чем в конце XIX в.

Очевидное видовое значение интересующих нас числительных выявляется, например, в следующих случаях:

(a) Cirkev vynáša neomylné rozhodnutia dvojím spôsobom: lebo skrze vseobecný (!) snem alebo skrze pápeža (Svätá Rodina 1915: 18);

(b) Od 1835-ho vychodily slovenčiace almanachy Zory, spojovavšie spisovatelov obojeho vierovyznania... (Škultéty 1920: 94). 
В современном словацком литературном языке, в отличие от чешского, приведенные формы сохранились только в функции собирательных, и процесс исчезновения у них видового значения осуществился в первой половине XX в. Кроме того, они полностью утратили склонение. В им. и вин. падежах собирательные числительные oboje, dvoje, troje изменили синтаксические свойства: до самого последнего времени они имели дублетные формы, так как могли употребляться с им. падежом мн. числа (dvoje noviny) аналогично чешскому языку или с род. (dvoje novín), однако в последней редакции «Правил словацкого правописания» первый вариант был исключен из словацкого литературного языка (Pravidlá 2013). Видовыми же в словацком литературном языке в настоящее время являются числительные с суфрфиксом $a k(y)$ (dvojaký, obojaký и т. д.) $)^{2}$.

Иные видовые адъективные числительные также претерпели изменения, поскольку некоторые из них, образованные по той же модели, что и в чешском языке, стали образовываться иначе. Ср. примеры:

(a) V našich bol’astach, mukách si nás prevýšila, premohúc bol'asti sedmorého (чеш. sedmerý; совр. словацк. sedmoraký) meča (Svätá Rodina 1915: 238);

(b) Storá (чеш. sterý; совр. словацк. storaký) zkúsenost nás učí, že nemocní bývajú v mnohom ohlade ako deti, a to je pravda (Gierlová 1910: 326).

В словацком литературном языке с конца XIX до 40-х гг. $\mathrm{XX}$ в. претерпели изменения сложные существительные, прилагательные и наречия, в состав которых входили числительные. У этих прилагательных компоненты oba, dva, tri, štyri, как и в чешском языке, первоначально имели форму родительного падежа, которая впоследствии была замене-

2 В чешском языке наряду с указанными именными формами представлены также адъективные видовые числительные dvojí, troji и т. д., отсутствующие в словацком языке. 
на основой соответствующих собирательных числительных. Ср. примеры:

(a) ...krstné svedectvo (bizonylat) dl'a predpisu... na všetky duchovné i svetské vrchnosti vydaného a obústranne (чеш. oboustranně, совр. слов. obojstranne) publikovaného (Katolické Noviny 1890: 90);

(b) Svojho štyrročného (чеш. čtyřletý, совр. слов. štvorročný) Jožka dali do súsedov k detoom (Svätá Rodina 1911: 327).

Дивергентные процессы затронули и грамматические свойства количественных числительных, но они реализовались только на уровне отдельных словоформ. Так, в парадигме числительного jeden в род. и дат. падежах ед. числа в текстах начала XX в. фиккируются фрормы с гласным $о$, совпадающие с чешскими:

...malú epizodku jednoho hrdinu rozviedli na samostatný nový epos alebo tragédiu... (Bujnák 1919: 78).

В 1930-е гг., однако, были кодифрицированы фрормы с гласным é во фрлексии (Pravidlá 1931: 146).

На протяжении всего XX века числительное $d v a / d v e$ в тв. падеже имело фрорму $d v o m a$, коррелирующую с чеш-

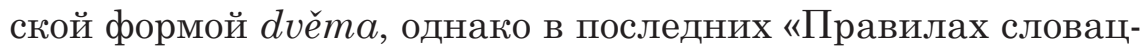
кого правописания» была введена дублетная форома dvomi (Pravidlá 2013), не имеющая аналога в чешском языке.

Таким образом, изменение грамматических свойств числительных является наглядным свидетельством активных дивергентных процессов, осуществлявшихся при интенсивном языковом контакте.

\section{Источники}

Bujnák 1919 - Bujnák P. Pavol Országh-Hviezdoslav. K 70-tym jeho narodeninám. Liptovský sv. Mikuláš: Tranoscius, 1919.

Gierlová 1910 - Gierlová E. Kvety s kríža. Trnava: Spolok sv. Adalberta (Vojtecha), 1910. 
Katolické Noviny — Katolické Noviny. Trnava, 1889-1890.

Svätá Rodina — Svätá Rodina. Liptovský Sv. Mikuláš, 1911-1915.

Škultéty 1920 - Škultéty J. Stodvadsatpät rokov zo slovenkého života 1790-1914. Odpoved’ na knihu dr. Milána Hodžu, nazvanú československý rozkol. 2. rozmnož. vyd. Turč. Sv. Martin, 1920.

\section{Литература}

Вайнрайх 1979 - Вайнрайх У. Языковые контакты. Состояние и проблемы исследования. Киев: Изд-во при Киевском гос. ун-те издат. объединения «Вища школа», 1979.

Поливанов 1968 - Поливанов $E$. Д. Мутационные изменения в звуковой истории языка // Поливанов E. Д. Избранные работы: статьи по общему языкознанию. М.: Главная редакция восточной литературы, 1968. C. $90-113$.

Krátky 1987 — Krátky slovník slovenského jazyka. Bratislava: Veda, 1987.

Pravidlá 1931 - Pravidlá slovenského pravopisu s abecedným pravopisným slovníkom. Praha: Štátne nakladatel'stvo (Státní nakladatelství), 1931.

Pravidlá 1940 - Pravidlá slovenského pravopisu s pravopisným slovníkom. Turč. Sv. Martin: Vydavatel'stvo Matice slovenskej, 1940.

Pravidlá 1954 - Pravidlá slovenského pravopisu s pravopisným a gramatickým slovníkom. Bratislava: Vydavatel'stvo SAV, 1954.

Pravidlá 2013 - Pravidlá slovenského pravopisu. Bratislava: Veda, 2013. Šmilauer 1972 - ̌̌milauer V. Nauka o českém jazyku. Praha: Státní pedagogické nakladatelství, 1972.

Štúr 1957 — Štúr L. Náuka reči slovenskej // Štúr L. Slovenčina naša: dielo v 5 zväzkoch. Zväzok 5. Bratislava: Slovenské vydavatel'stvo krásnej literatúry, 1957. S. 151-253.

\section{Divergence of the Slovak and Czech Literary Languages in the $\mathrm{XX}^{\text {th }}$ Century at the Grammatical Level (on the example of numerals)}

According to traditional contact linguistics, the result of close linguistic contact is interference, which initially occurs at the level of speech, but can also be reflected at the level of language. At the same time, as the Slovak and Czech literary languages show, the 
consequence of close linguistic contact can also be pronounced divergent processes. This article focuses on morphological and wordformation changes that have significantly changed the grammatical properties of numerals in Slovak literary language, while in Czech they remained unchanged.

DOI: $10.31168 / 0459-6.07$

$$
\begin{array}{r}
\text { М. Г. Джонова (София, България), } \\
\text { С. И. Лесева (София, България), } \\
\text { Е. Ю. Иванова (Санкт-Петербург, Русия) }
\end{array}
$$

\section{Инхоативни глаголи с дателен експериенцер в българския език ${ }^{1}$}

В настоящата статията се прави синтактично описание на инхоативните глаголи от типа на домъчнее/дольчнява ми в съвременния български език. Те имат задължителен аргумент дателно местоимение със семантичната роля експериенцер и означават ново състояние на субекта. В деривационно отношение се свързват със съществителни, прилагателни или наречия за фризиологично, ментално или емоционално състояние, вж. (Радева 1993). В семантично отношение разглежданите глаголи съответстват на синтактичните конструкции с предикатив за състояние и дателно местоимение. В някои случаи те се свързват пряко с предикатива (зле ми е - призлее / призлява ми), а в други (студено - застудее / застудява ми, тьжно - дотьжее / доть-

1 Настоящият текст е резултат от изпълнението на научната програма на проекта «Онтология на ситуациите за състояние - лингвистично моделиране. Съпоставително изследване за български и руски», подкрепен от Фонд «Научни изследвания» в рамките на конкурса «Проекти по програма за двустранно сътрудничество - България - Русия 2019-2020 г.», договор № КП-06-П РУСИЯ-78 от 2020 г. и РФФИ (проект № 20-512-18005). 